\title{
Oxidative phosporylation in human muscle in patients with ocular myopathy and after general anaesthesia
}

\author{
H.R. Scholte ${ }^{1}$, E. Agsteribbe ${ }^{2}$, H.F.M. Busch ${ }^{3}$, T.U. Hoogenraad ${ }^{4}$, F.G.I. Jennekens ${ }^{4}$, \\ B. van Linge ${ }^{5}$, I.E.M. Luyt-Houwen ${ }^{1}$, J.D. Ross ${ }^{1}$, M.H.J. Ruiters ${ }^{2}$ \\ and M.H.M. Verduin ${ }^{6}$ \\ Departments of ${ }^{I}$ Biochemistry I, ${ }^{3}$ Neurology, ${ }^{5}$ Orthopaedy, ${ }^{6}$ Clinical Genetics, Erasmus University, Rotterdam, ${ }^{2}$ Laboratory of \\ Physiological Chemistry, State University, Groningen and ${ }^{4}$ Department of Neurology, University Hospital, Utrecht (The Netherlands)
}

(Received 1 May 1990)

Key words: Ophthalmoplegia, chronic progressive external; Muscle mitochondrion; Kearns-Sayre syndrome; Mitochondrial defect; DNA, mitochondrial; Oxidative phosphorylation; (Human)

The fuel preference of human muscle mitochondria has been given. Substrates which are oxidized with low velocity cannot be used to detect defects in oxidative phosphorylation. After general anaesthesia, the oxygen uptake with the different substrates is much lower than after local analgesia. The latter was therefore used in the subsequent study. In 15 out of 18 patients with ocular myopathy, defects in oxidative phosporylation could be detected in isolated muscle mitochondria prepared from freshly biopsied tissue. Measurement of the activity of segments of the respiratory chain in homogenate from frozen muscle showed no, or minor defects. In two of these patients showing exercise intolerance, decreased oxidation of $\mathrm{NAD}^{+}$-linked substrates and apparently normal mitochondrial DNA, further study revealed deficiency of pyruvate dehydrogenase in a girl with ptosis and a high $K_{m}$ of complex I for NADH in a man. Both patients responded to vitamin therapy.

\section{Introduction}

The study of failing mitochondria in man is a rapidly expanding field of interest [1-12]. Mitochondrial dysfunction is encountered in an increasing number of patients, and deficiencies have been reported of more than 65 mitochondrial proteins (enzymes or carriers) [7]. For the detection of defects in the mitochondrial energy transduction, skeletal muscle is the preferred tissue, also when the involvement of other organs in the disease process is more prominent.

Extensive research revealed that many patients in fact suffered from multiple mitochondrial defects [7,1517]. In order to detect these defects we advocate a functional study of isolated mitochondria from freshly biopsied muscle in combination with assay of relevant mitochondrial activities and muscle markers in homo-

\footnotetext{
Abbreviations: CPEO, chronic external ophthalmoplegia; TMPD tetramethyl phenylenediamine; RCI, respiratory control index; mtDNA, mitochondrial DNA.

Correspondence: H.R. Scholte, Department of Biochemistry I, Erasmus University, P.O. Box 1738, 3000 DR Rotterdam, The Netherlands.
}

genate from frozen muscle $[8,13,14,18,19]$. In the present work this approach was used for the investigation of 18 patients with ocular myopathy.

In chronic external ophthalmoplegia (CPEO), weakness may be confined to the eye muscles. More often, it is only part of the clinical picture. The Kearns-Sayre syndrome has been separated out as a distinct form of CPEO and characterized by onset in childhood or adolescence, atypical retinopathy, heart block and raised CSF protein. Young patients with CPEO may develop the full Kearns-Sayre syndrome later [20,21].

Many groups tried to unravel the etiology of the ocular myopathies [1,19-42]. As suggested by the increased mitochondrial masses in part of the muscle fibres of most patients and by the increased blood lactate levels, defective mitochondria could play a role in the pathophysiology of the disease. An impressive amount of different mitochondrial defects have been reported in one or more of the patients studied (some were normal), such as abnormal oxidative phosporylation in isolated muscle mitochondria $[1,19,20,22,23,26$, $34,40]$, decreased activity or concentration of CoQ $[1,29,31,35,41]$, Complex I [19,40], Complex I + IV [34], Complex III [1], Complex III + IV [1,24], Complex IV $[30,32,35,37]$, complete absence of Complex IV in some 
muscle fibres only $[25,27]$, uncoupler-stimulated $\mathrm{Mg}^{2+}$ ATPase [20], palmitoyl-CoA synthetase [28], mitochondrial translation product [33], Complex II [39], Complex I and/or III, Complex I and/or IV [40], a defective interaction between cytochrome $c$ and Complex IV [37] and finally heteroplasmy of mitochondrial DNA $[36,38,40,42]$, with different amounts of the deleted mitochondrial DNA of the same size in different tissues [42]. It is obvious that ocular myopathy is caused by a variety of different mitochondrial defects. Each of these defects, on the other hand, may give rise to a mitochondrial disease without involvement of the eye muscles.

\section{Methods}

Mitochondria were isolated from $0.12 \mathrm{~g}$ or more of freshly biopsied muscle, obtained under local analgesia (lidocain plus epinephrine), within $1.5 \mathrm{~h}$, according to the procedure of Bookelman et al. [43]. The surgical patients received different combinations of anaesthetics $\left(\mathrm{N}_{2} \mathrm{O}\right.$, ethrane, sodium $\gamma$-hydroxybutyrate), muscle relaxants (succinylcholine chloride, pancuronium bromide) and analgetic (fentanyl). The biopsies were taken at the end of the operation, which lasted 2-3 h from the onset of pharmacological pre-treatment. The following assays were performed: oxidative phosphorylation with various substrates (concentrations see Table I) was carried out in the presence of glucose, $\mathrm{Mg}^{2+}$ and hexokinase [44] as described in Ref. 13. The oxygen uptake rate with ascorbate plus TMPD has been corrected for auto-oxidation. The $\mathrm{P} / \mathrm{O}$ ratios (mol glucose 6-phosphate formed $/ 0.5 \mathrm{~mol} \mathrm{O}_{2}$ consumed) were determined by sampling just before the addition of ADP to correct for the presence of mitochondrial adenine nucleotides [45]. This gave rise to a considerable decrease in $\mathrm{P} / \mathrm{O}$ ratios (compare Ref. 13). The average $\mathrm{P} / \mathrm{O}$ ratios with pyruvate plus malate, glutamate plus malate, palmitoylcarnitine plus malate, succinate plus rotenone and ascorbate plus TMPD in the control patients were $1.66,1.73,1.80,1.19$ and 0.44 respectively, and were not significantly different in the other groups. $\mathrm{Mg}^{2+}$-ATPase was measured without and with 2,4-dinitrophenol [13]. [U- ${ }^{14} \mathrm{C}$ ]Palmitate oxidation was measured with $1 \mathrm{mM} \mathrm{KCN}$ to measure the peroxisomal beta oxidation, and with $0.5 \mathrm{mM} \mathrm{L}$-carnitine to measure the mitochondrial contribution as well [46]. Malonyl-CoA decarboxylase was measured as in Ref. 8, without and with detergent and showed a high level of integrity of the inner membranes. The assays in the homogenate were carried out as described in Ref. 19. Pyruvate dehydrogenase and 2-ketoglutarate dehydrogenase were determined as in Ref. 47.

DNA was isolated from 1-5 mg muscle. The tissue was lysed in $330 \mu 1$ of $50 \mathrm{mM}$ Tris, $100 \mathrm{mM}$ EDTA, 200 $\mathrm{mM} \mathrm{NaCl}$ and 1\% SDS (pH 9.0). Proteinase $\mathrm{K}$ was added to a final concentration of $0.2 \mathrm{mg} / \mathrm{ml}$ and the

TABLE I

Fuel preference of human muscle mitochondria

\begin{tabular}{|c|c|c|c|}
\hline $\begin{array}{l}\text { Oxidative substrates } \\
(\mathrm{mM})\end{array}$ & $\begin{array}{l}\text { Oxygen uptake } \\
\text { rate (ng atom } \mathrm{O}_{2} \text { per } \\
\text { min per mg protein) }\end{array}$ & $\begin{array}{l}\text { Stimulation of } \\
\text { oxygen uptake } \\
\text { rate by ADP (RCI) }\end{array}$ & $\overline{n^{a}}$ \\
\hline \multicolumn{4}{|l|}{$\mathrm{NAD}^{+}$-linked } \\
\hline Pyruvate $5+$ L-malate 2.5 & $82 \pm 5(50-144)^{b}$ & $2.48 \pm 0.17(1.52-4.05)^{b}$ & 22 \\
\hline Glutamate $5+$ malate 2.5 & $82 \pm 7(45-170)$ & $2.41 \pm 0.13(1.36-3.75)$ & 22 \\
\hline 2-Ketoglutarate 10 & $59 \pm 5(41-181)$ & $2.11 \pm 0.21(1.56-4.42)$ & 14 \\
\hline \multicolumn{4}{|l|}{ DL-Acetylcarnitine 2.5} \\
\hline+ malate 0.5 & $52 \pm 4(31-81)$ & $2.02 \pm 0.13(1.44-3.09)$ & 14 \\
\hline DL-3-Hydroxybutyrate 10 & 18 & 1.00 & 1 \\
\hline DL-Isocitrate 10 & $18 \pm 6(11-29)$ & $0.70 \pm 0.11(0.50-0.86)$ & 3 \\
\hline \multicolumn{4}{|l|}{$\mathrm{NAD}^{+}-$and CoQ-linked } \\
\hline \multicolumn{4}{|l|}{ Palmitoylcarnitine 0.02} \\
\hline+ malate 0.6 & $68 \pm 5(40-111)$ & $2.16 \pm 0.16(1.35-4.25)$ & 22 \\
\hline \multicolumn{4}{|l|}{ CoQ-linked } \\
\hline \multicolumn{4}{|l|}{ Succinate 5} \\
\hline + rotenone 0.003 & $104 \pm 8 \quad(62-196)$ & $2.17 \pm 0.11(1.50-3.38)$ & 22 \\
\hline \multicolumn{4}{|l|}{ Duroquinol $0.75 \mathrm{mM}$} \\
\hline+ catalase & $154 \pm 21(100-212)$ & $2.25 \pm 0.48(1.27-4.09)$ & 5 \\
\hline DL-Glycerol 3-phosphate 10 & $23 \pm 4(12-36)$ & $1.11 \pm 0.09(0.88-1.52)$ & 7 \\
\hline \multicolumn{4}{|l|}{ Cytochrome $c$-linked } \\
\hline Ascorbate 5+ TMPD 0.6 & $344 \pm 13(231 \pm 469)$ & $1.65 \pm 0.07(1.28-2.79)$ & 22 \\
\hline
\end{tabular}

a $n=$ number of patients tested.

b Values \pm S.E.M.; range in parentheses. 
tissue was digested for at least $16 \mathrm{~h}$ at $37^{\circ} \mathrm{C}$ until lysis was complete. A $6 \mathrm{M} \mathrm{NaCl}$ solution was added to a final concentration of $1.5 \mathrm{M} \mathrm{NaCl}$ [48]. Protein and SDS were precipitated by centrifugation for $10 \mathrm{~min}$ at $1000 \times g$. DNA was precipitated from the supernatant by adding 2 vol. of ethanol followed by centrifugation for $10 \mathrm{~min}$ at $12000 \times \mathrm{g}$. The supernatant was discarded, and after vacuum evaporation the DNA pellet was dissolved in $10 \mu 1$ bidest per mg of tissue. Average DNA yield is $10 \mu \mathrm{g}$ per mg muscle tissue.

For restriction analysis, $10 \mu 1$ DNA suspension was restricted with Bam $\mathrm{HI}$ and separated on a $0.8 \%$ agarose gel [49]. DNA was blotted onto Genescreen Plus and hybridized [50] with a $\left[{ }^{32} \mathrm{P}\right] \mathrm{dCTP}$ random prime labelled mitochondrial DNA clone containing the $16 \mathrm{~S}$ and $12 \mathrm{~S}$ ribosomal RNA genes (a generous gift of Dr. G. Attardi). Filters were exposed to Kodak XAR-5 films for $72 \mathrm{~h}$ using an intensifying screen.

\section{Results and Discussion}

\section{Substrates of human muscle mitochondria}

Mitochondria in different tissues and cells oxidize substrates with different rates according to their meta- bolic role in the cell. Table I shows the oxygen uptake rates with different oxidative substrates, catalyzed by human skeletal muscle mitochondria. Isocitrate, 3-hydroxybutyrate and glycerol 3-phosphate are slowly oxidized. The former substrate because of the absence of the citrate carrier in muscle mitochondria [51], and the latter substrates due to the fact that their dehydrogenases have a relatively low activity. The stimulation of the $\mathrm{O}_{2}$ uptake rate with ADP (RCI, respiratory control index) is low with these substrates (Table I). A low respiratory rate is accompanied by a low RCI. In earlier work we found that this apparently loose coupling occurred when the respiratory rate fell below 30 ngatom $\mathrm{O}_{2}$ per min per $\mathrm{mg}$ protein [45]. The integrity of the mitochondrial oxidative phosphorylation can only be challenged with substrates which are oxidized with a relatively high rate and RCI. The other substrates of Table I meet these criteria. When possible, we studied oxidative phosphorylation with the substrates used in Table II. When more mitochondria were available, and the oxidative phosphorylation was not normal, we tried to identify the defect more precisely by using some of the other substrates. When only a few oxygen traces

\section{TABLE II}

Oxidative phosphorylation in isolated muscle mitochondria in patients with ocular myopathy and in control patients, both groups after local analgesia and in surgical patients after general anaesthesia

Nr., number. Age is expressed in years. Sex: F, female and M, male. Syndr., syndrome; CPEO, chronic progressive external ophthalmoplegia; KSS, Kearns-Sayre syndrome. The oxygen uptake rates were measured in the presence of ADP and $\mathrm{P}_{\mathrm{i}}$ at $25^{\circ} \mathrm{C}$ with Pyr (pyruvate plus malate), Glut (glutamate plus malate), Palm (palmitoylcarnitine plus malate), Succ (succinate plus rotenone), Asc (ascorbate plus TMPD) and expressed in ngatoms of oxygen consumed per min per mg protein. RCI, respiratory control index, the stimulation of the oxygen uptake rate by ADP with ascorbate plus TMPD. The mitochondrial ATP synthetase was measured as $\mathrm{Mg}^{2+}$-ATPase and expressed in nmol ATP per min per mg protein. DNP, 2,4-dinitrophenol.

\begin{tabular}{|c|c|c|c|c|c|c|c|c|c|c|c|}
\hline \multirow[t]{2}{*}{ No. } & \multirow[t]{2}{*}{ Age } & \multirow[t]{2}{*}{ Sex } & \multirow[t]{2}{*}{ Syndr. } & \multicolumn{5}{|c|}{$\mathrm{O}_{2}$-uptake rates with } & \multirow{2}{*}{$\begin{array}{l}\text { RCI } \\
\text { Asc }\end{array}$} & \multicolumn{2}{|l|}{ ATPase } \\
\hline & & & & Pyr & Glut & Palm & Succ & $\overline{\mathrm{Asc}}$ & & $-\mathrm{DNP}$ & $+\mathrm{DNP}$ \\
\hline 1 & 8 & $F$ & CPEO & 20 & 31 & 32 & 81 & 349 & 1.56 & 33 & 270 \\
\hline 2 & 11 & $\mathbf{M}$ & KSS & 63 & 69 & 60 & 79 & 233 & 1.76 & 5 & 531 \\
\hline 3 & 12 & $\mathrm{~F}$ & KSS & 23 & 31 & 23 & 55 & 283 & 1.29 & 65 & 341 \\
\hline 4 & 18 & $\mathbf{M}$ & KSS & 36 & 30 & 30 & 72 & 213 & 1.89 & 89 & 447 \\
\hline 5 & 21 & $\mathbf{M}$ & KSS & 18 & 38 & 26 & 31 & 341 & 1.52 & 42 & 1221 \\
\hline 6 & 23 & $\mathbf{M}$ & CPEO & 57 & 54 & 42 & 61 & 314 & 1.52 & 43 & 638 \\
\hline 7 & 26 & $\mathbf{M}$ & CPEO & 13 & 26 & 21 & 93 & 244 & 1.58 & 61 & 767 \\
\hline 8 & 28 & $\mathrm{~F}$ & CPEO & 47 & 42 & 54 & 107 & 379 & 1.45 & 14 & 129 \\
\hline 9 & 31 & $\mathrm{~F}$ & CPEO & 28 & 28 & 30 & 50 & 167 & 0.96 & 24 & 257 \\
\hline 10 & 31 & $\mathbf{M}$ & CPEO & 9 & 9 & 41 & 13 & 207 & 1.24 & 30 & 759 \\
\hline 11 & 32 & $\mathbf{M}$ & KSS & 67 & 73 & 70 & 13 & 377 & 1.78 & 29 & 600 \\
\hline 12 & 35 & $\mathbf{M}$ & CPEO & 80 & 69 & 60 & 105 & 374 & 1.36 & 15 & 492 \\
\hline 13 & 39 & $\mathbf{M}$ & CPEO & 67 & 63 & 42 & 63 & 225 & 1.15 & 77 & 309 \\
\hline 14 & 39 & $\mathbf{M}$ & CPEO & 42 & 38 & 43 & 78 & 300 & 0.87 & 54 & 303 \\
\hline 15 & 41 & $\mathbf{M}$ & CPEO & 51 & 46 & 35 & 54 & 250 & 1.23 & 41 & 547 \\
\hline 16 & 42 & $\mathbf{M}$ & CPEO & 15 & 20 & 22 & 45 & 177 & 1.38 & 58 & 229 \\
\hline 17 & 46 & $\mathbf{F}$ & KSS & 33 & 33 & 32 & 58 & 200 & 1.26 & 9 & 111 \\
\hline 18 & 53 & $\mathbf{F}$ & CPEO & 80 & 92 & 69 & 86 & 315 & 1.17 & 19 & 427 \\
\hline \multicolumn{4}{|c|}{ Controls $(n=22)$} & 82 & 82 & 68 & 104 & 344 & 1.65 & 44 & 603 \\
\hline \multicolumn{4}{|c|}{ S.E.M. } & 5 & 7 & 5 & 8 & 13 & 0.07 & 10 & 55 \\
\hline \multirow{2}{*}{\multicolumn{4}{|c|}{$\begin{array}{l}\text { Surgical patients }(n=5) \\
\text { S.E.M }\end{array}$}} & 31 & 36 & 26 & 41 & 164 & 1.55 & 26 & 434 \\
\hline & & & S.E.M. & 5 & 4 & 6 & 5 & 28 & 0.11 & 12 & 103 \\
\hline
\end{tabular}


could be obtained, we preferred combined assays with substrates and inhibitors [13].

\section{Control patients}

It is important that the oxidative performance of patient mitochondria is compared with proper controls. The number of mitochondria is decreased in fetal, neonatal and disused muscle, and increased in endurance sporters. Therefore we prefer control patients with about the same exercise pattern. These patients were biopsied because of the fact that they suffered from chronic muscle problems. With clinical, histopathological and biochemical methods no evidence could be detected for a neuromuscular defect. Since the results obtained in different laboratories differ greatly [52], control and patient studies must be performed in the same laboratory.

Surgical patients are often used as controls. In the past we have found that their muscle contained less carnitine than our control patients [53], and we wondered if the mitochondrial function was disturbed. This was indeed the case (Table II). We found a severe impairment of the respiratory rates with all substrates tested. The $\mathrm{NAD}^{+}$-linked substrates and succinate were oxidized with $40 \%$ and ascorbate with $48 \%$ of control activity. Surprisingly, the efficiency and coupling of oxidative phosphorylation were not significantly altered as expressed by the normal $\mathrm{P} / \mathrm{O}$ values (not shown) and $\mathrm{RCI}$ values. Also, ATP synthetase, measured as $\mathrm{Mg}^{2+}$ ATPase activity, was similar to control values. The basic activity was low and the stimulation by uncoupler high. For the complete investigation and a discussion see Ref. 54.

Hoppel et al. [55] presented control mitochondria from skeletal muscle of surgical patients with average respiratory rates of 31 ngatom $\mathrm{O}_{2}$ per $\mathrm{min}$ per $\mathrm{mg}$ protein with pyruvate plus malate, 25 with glutamate, 26 with palmitoylcarnitine plus malate and 52 for succinate plus rotenone, measured at $30^{\circ} \mathrm{C}$, agreeing very well with our observations at $25^{\circ} \mathrm{C}$.

\section{Ocular myopathy}

The results of the oxidative phosphorylation in the individual patients with ocular myopathy are summarized in Table II. From comparison with the results of the activity of the segments of the respiratory chain (Table III), it is clear that most defects in the mitochondrial energy transduction can only be measured in intact mitochondria, and not in homogenate from frozen muscle. Normal oxidative phosphorylation was found in

\section{TABLE III}

The activity of segments of the mitochondrial respiratory chain, the amount of protein and carnitine and the activity of creatine kinase in muscle homogenates of patients with ocular myopathies and control patients

I, rotenone-sensitive NADH oxidase, in $\mu \mathrm{mol} \mathrm{NADH/min.} \mathrm{II,} \mathrm{succinate} \mathrm{dehydrogenase,} \mathrm{in} \mu \mathrm{mol}$ 2-p-iodophenyl-3-p-nitrophenyl-5-phenyltetrazolium $/ \mathrm{min}$. II + III, antimycin-sensitive succinate cytochrome $c$ reductase, in $\mu \mathrm{mol}$ cytochrome $c / \mathrm{min}$. IV, Cytochrome $c$ oxidase, in first order rate constant $k / \mathrm{min}$. Prot, protein, in $\mathrm{mg}$. Carn, total carnitine, in $\mu \mathrm{mol}$. CK, creatine kinase, in $\mu$ mol creatine/min. The data above were calculated per $\mathrm{g}$ wet weight. The sizes of the mitochondrial DNA were given in kilobase.

\begin{tabular}{|c|c|c|c|c|c|c|c|c|c|}
\hline \multirow[t]{2}{*}{ Nr. } & \multicolumn{7}{|c|}{ Respiratory chain } & \multicolumn{2}{|c|}{ Mitochondrial DNA } \\
\hline & $\bar{I}$ & II & II + III & IV & Prot & Carn & $\overline{\mathrm{CK}}$ & main band(s) & satellite \\
\hline 1 & 2.14 & 0.93 & 6.88 & 115 & 144 & 3.56 & 307 & 16.5 & No \\
\hline 2 & 3.45 & 0.78 & & 107 & 218 & 2.52 & 259 & 16.5 & 12.5 \\
\hline 3 & 3.28 & 1.46 & 9.89 & 124 & 170 & 2.41 & 367 & 16.5 & 33.0 \\
\hline 4 & 1.40 & 0.81 & 5.73 & 29 & 183 & 2.77 & 418 & 13.0 & 16.5 \\
\hline 5 & 2.92 & 0.87 & 1.57 & 137 & 180 & 5.37 & 248 & & \\
\hline 6 & 4.87 & 0.95 & 4.84 & 164 & 153 & 3.11 & 277 & 16.5 & no \\
\hline 7 & 2.67 & 0.60 & 2.99 & 90 & & 2.28 & 341 & 16.5 & no \\
\hline 8 & 2.40 & 0.74 & 3.81 & 102 & 186 & 3.62 & 241 & 16.5 & 14.0 \\
\hline 9 & 2.98 & 0.97 & 5.39 & 108 & 213 & 2.91 & 260 & 16.5 & 33.0 \\
\hline 10 & & 0.80 & 4.82 & 80 & 141 & 2.92 & 399 & & \\
\hline 11 & & 0.62 & 1.28 & & 144 & 4.46 & 256 & & \\
\hline 12 & 3.54 & 0.93 & 5.29 & 76 & 130 & 3.30 & 296 & 16.5 & no \\
\hline 13 & 2.14 & 0.88 & 3.85 & 55 & 105 & 2.91 & 315 & $16.5 ; 14.0$ & no \\
\hline 14 & 1.64 & 0.59 & 8.70 & 57 & 85 & 2.34 & 266 & 16.5 & 13.0 \\
\hline 15 & & 0.82 & 4.71 & 67 & 186 & 2.68 & 288 & & \\
\hline 16 & 1.01 & 0.48 & 2.21 & 34 & 185 & 2.44 & 278 & 33.0 & no \\
\hline 17 & 2.10 & 1.16 & 3.48 & 66 & 198 & 2.10 & 286 & 16.5 & no \\
\hline 18 & 1.75 & 0.77 & 4.10 & 94 & 183 & 3.71 & 197 & 16.5 & no \\
\hline Contr. & 3.19 & 0.72 & 3.99 & 90 & 174 & 3.96 & 307 & 16.5 & no \\
\hline S.E.M. & 0.26 & 0.04 & 0.43 & 7 & 6 & 0.09 & 12 & & \\
\hline$n$ & 10 & 58 & 21 & 16 & 53 & 59 & 50 & & \\
\hline
\end{tabular}


three patients, while it was abnormal in 15 patients. Four of them showed a low oxidation rate with the $\mathrm{NAD}^{+}$-linked substrates only, one showed also a low rate with succinate, one showed only a low oxidation rate with succinate (for discussion see Ref. 19), three showed low rates with all substrates. Uncoupler-stimulated $\mathrm{Mg}^{2+}$-ATPase had a low activity in two patients, and an abnormally low stimulation of the respiratory rate with ascorbate plus TMPD by ADP was encountered in six patients, pointing to a defect in complex $\mathrm{V}$, the adenine nucleotide translocator or the $\mathrm{P}_{\mathrm{i}}$-translocator. Mitochondrial enzyme activities were normal in 14 of the patients. Two showed a decreased activity of complex I and IV and two of complex IV only. These decreases could not explain the severe depression of the oxidative phosphorylation. The muscle markers total carnitine and creatine kinase were normal or slightly below normal in all patients (Table III).

In 14 patients, restriction analysis was performed with mitochondrial DNA. Apparently normal mtDNA was detected in six, heteroplasmy in six, and mtDNA of twice the size in controls was found in three patients. In one of these it is the only band visible. Two of the patients showed the lowest oxidation rate with ascorbate. mtDNA of double length has not been reported before and its appearance is puzzling.

Further research into the nature of the mitochondrial defect in muscle homogenate was successful in a girl (patient 1) and a man (patient 7) both suffering from lifelong exercise intolerance by fatigue, having decreased oxidation rate with $\mathrm{NAD}^{+}$-linked substrates and (apparently) normal mtDNA. The girl showed a deficiency of pyruvate dehydrogenase (after preincubation with $\mathrm{Ca}^{2+}$ plus $\mathrm{Mg}^{2+} 188 \mathrm{mU} / \mathrm{g}$ wet weight vs. $922 \pm 102$ (S.E.) $\mathrm{mU} / \mathrm{g}$ wet weight in nine controls. 2-Ketoglutarate dehydrogenase $442 \mathrm{mU} / \mathrm{g}$ wet weight vs. $1091 \pm 156$ (S.E.) in 11 controls). She received thiamin and riboflavin, and her ptosis disappeared within 8 months, while her plasma lactate decreased from $4.2 \mathrm{mM}$ to $1.9 \mathrm{mM}$ (controls: $0.6-1.8 \mathrm{mM}$ ). In the man an increased $K_{\mathrm{m}}$ of NADH oxidase for complex I was found (Ref. 19) and he improved significantly by nicotinamide. The man had a normal activity of pyruvate dehydrogenase.

\section{Acknowledgements}

The 'Prinses Beatrix Fonds' is acknowledged for financial support in Groningen and Rotterdam and Mrs. A.C. Hanson for typing this paper.

\section{References}

1 DiMauro, S., Bonilla, E. Zeviani, M., Nakagawa, M. and DeVivo, D.C. (1985) Ann. Neurol. 17, 521-538.
2 Morgan-Hughes, J.A. (1986) in Myology (Engel, A.G. and Banker, B.Q. eds.), pp. 1709-1743, McGraw-Hill, New York.

3 Capaldi, R.A., Halphen, D.G., Zhang, Y.Z. and Yanamura, W. (1988) J. Bioenerg. Biomembr. 20, 291-311.

4 DiMauro, S., Zeviani, M., Rizzuto, R., Lombes, A., Nakase, H., Bonilla, E., Miranda, A. and Schon, E. (1988) J. Bioenerg. Biomembr. 20, 353-364.

5 Kennaway, N.G. (1988) J. Bioenerg. Biomembr. 20, 325-352.

6 Morgan-Hughes, J.A., Schapira, A.H., Cooper, J.M. and Clark, J.B. (1988) J. Bioenerg. Biomembr. 20, 365-382.

7 Scholte, H.R. (1988) J. Bioenerg. Biomembr. 20, 161-191.

8 Scholte, H.R., Busch, H.F.M., Luyt-Houwen, I.E.M. Przyrembel, H. and Vaandrager-Verduin, M.H.M. (1988) in Biomembranes (Benga, Ch. and Tager, J.M., eds.), pp. 107-129, Springer, Berlin.

9 Sherratt, H.S.A. Watmough, N.J., Johnson, M.A. and Turnbull, D.M. (1988) Methods Biochem. Anal. 33, 243-335.

10 Trijbels, J.M.F., Sengers, R.C.A., Ruitenbeek, W., Fischer, J.C., Bakkeren, J.A.J.M. and Janssen, A.J.M. (1988) Eur. J. Pediatr. 148, 92-97.

11 Frerman, F.E. and Goodman, S.I. (1989) in The Metabolic Basis of Inherited Disease (Scriver, C.R., Beaudet, A.L., Sly, W.S. and Valle, D., eds.), pp. 915-931, McGraw-Hill, New York.

12 Robinson, B.H. (1989) in The Metabolic Basis of Inherited Disease (Scriver, C.R., Beaudet, A.L., Sly, W.S. and Valle, D., eds.), pp. 869-888, McGraw-Hill, New York.

13 Barth, P.G., Scholte, H.R., Berden, J.A., Van der Klei-van Moorsel, J.M., Luyt-Houwen, I.E.M., Van 't Veer-Korthof, E.Th., Van der Harten, J.J. and Sobotka-Plojhar, M.A. (1983) J. Neurol. Sci. 62, 327-355.

14 Roodhooft, A.M., Van Acker, K.J., Martin, J.J., Ceuterick, C., Scholte, H.R. and Luyt-Houwen, I.E.M. (1986) Neuropediatrics 17, 221-226.

15 Tanaka, M., Nishikimi, M., Suzuki, H., Ozawa, T., Okino, E. and Takahashi, H. (1986) Biochem. Biophys. Res. Commun. 137, 911916.

16 Byrne, E., Trounce, I., Dennett, X., Gilligan, B., Morley, J.B. and Marzuki, S. (1988) J. Neurol. Sci. 88, 327-337.

17 Tanaka, M., Miyabayashi, S., Nishikimi, M., Suzuki, H., Shimomura, Y., Ito, K., Narasawa, K., Tada, K. and Ozawa, T. (1988) Pediatr. Res. 24, 447-454.

18 Scholte, H.R. and Busch, H.F.M. (1988) Ann. Clin. Biochem. 25, $27 s-34 s$.

19 Scholte, H.R., Busch, H.F.M., Luyt-Houwen, I.E.M., VaandragerVerduin, M.H.M., Przyrembel, H. and Arts, W.F.M. (1987) J. Inher. Metabol. Dis. 10 (Suppl. 1), 81-97.

20 Berenberg, R.A., Pellock, J.M., DiMauro, S., Schotland, D.L., Bonilla, E., Eastwood, A., Hays, A., Vicale, C.T., Behrens, M., Chutorian, A. and Rowland, L.P. (1977) Ann. Neurol. 1, 37-54.

21 Rowland, L.P., Hays, A.P., DiMauro, S., DeVivo, D.C. and Behrens, M. (1983) in Mitochondrial Pathology in Muscle Diseases (Scarlato, G. and Cerri, C., eds.), pp. 141-158, Piccin, Padua.

22 DiMauro, S., Schotland, D.L., Bonilla, E., Lee, C.-P., Gambetti, P. and Rowland, L. (1973) Arch. Neurol. 28, 170-179.

23 Bastiaensen, L.A.L., Joosten, E.M.G., De Rooij, J.A.M., Hommes, O.R., Stadhouders, A.M., Jaspar, H.H.J., Veerkamp, J.H., Bookelman, H. and Van Hinsbergh, V.W.M. (1978) Acta Neurol. Scand. $58,9-34$.

24 Allen, R.J., DiMauro, S., Coulter, D.L., Papadimitriou, A. and Rothenberg, S.P. (1983) Ann. Neurol. 13, 679-682.

25 Johnson, M.A., Turnbull, D.M., Dick, D.J. and Sherratt, H.S.A. (1983) J. Neurol. Sci. 60, 31-53.

26 Mitsumoto, H., Aprille, J.R., Wray, S.H., Nemni, R. and Bradley, W.G. (1983) Neurology 33, 452-461.

27 Müller-Höcker, J., Pongratz, D. and Hübner, G. (1983) Virchow's Arch. Path. Anat. 402, 61-71.

28 Niebrój-Dobosz, I., Ryniewicz, B., Fidziańska, A. and Badurska, B. (1985) Neurology $35,1582-1586$. 
29 Ogasahara, S., Yorifuji, S., Nishikawa, Y., Takahashi, M., Wada, K., Hazama, T., Nakamura, Y., Hashimoto, S., Kono, N. and Tarui, S. (1985) Neurology 35, 372-377.

30 Yorifuji, S., Ogasahara, S., Takahashi, M. and Tarui, S. (1985) J. Neurol. Sci. 71, 65-75.

31 Ogasahara, S., Nishikawa, Y., Yorifuji, S., Soga, F., Nakamura, Y., Takahashi, M., Hashimoto, S., Kono, N. and Tarui, S. (1986) Neurology 36, 45-53.

32 Bresolin, N., Moggio, M., Bet, L., Gallanti, A., Prelle, A., NiboleOrazio, E., Adobbati, L., Ferrante, C., Pellegrini, G. and Scarlato, G. (1987) Ann. Neurol. 21, 564-572.

33 Byrne, E., Marzuki, S., Sattayasai, N., Dennett, X. and Trounce, I. (1987) Neurology 37, 1530-1534.

34 Driessen-Kletter, M., Bär, P.R., Scholte, H.R. and Hoogenraad, T.U. (1987) J. Inher. Metab. Dis. 10 (Suppl. 2), 252-255.

35 Bresolin, N., Bet, L., Binda, A., Moggio, M., Comi, G., Nador, F., Ferrante, C., Carenzi, A. and Scarlato, G. (1988) Neurology 38, 892-899.

36 Lestienne, P. and Ponsot, G. (1988) Lancet i, 885.

37 Martens, M.E., Peterson, P.L., Lee, C.P., Nigro, M.A., Hart, Z., Glasberg, M., Hatfield, J.S. and Chang, C.H. (1988) Ann. Neurol. 24, 630-637.

38 Zeviani, M., Moraes, C.T., DiMauro, S., Nakase, H., Bonilla, E., Schon, E.A. and Rowland, L.P. (1988) Neurology 38, 1339-1346.

39 Rivner, M.H., Shamsnia, M., Swift, T.R., Trefz, J., Roesel, R.A., Carter, A.L., Yanamura, W. and Hommes, F.A. (1989) Neurology $39,693-696$.

40 Holt, I.J., Harding, A.E., Cooper, J.M.M., Schapira, A.H.V., Toscano, A., Clark, J.B. and Morgan-Hughes, J.A. (1989) Ann. Neurol. 26, 699-708.

41 Zierz, S., Jahns, G. and Jeruzalem, F. (1989) J. Neurol. 236, 97-101.
42 Shanske, S., Moraes, C.T., Lombes, A., Miranda, A.F., Bonilla, E., Lewis, P., Shelan, M.A., Ellsworth, C.A. and DiMauro, S. (1990) Neurology 40, 24-28.

43 Bookelman, H., Trijbels, J.M.F., Sengers, R.C.A. and Janssen, A.M.J. (1978) Biochem. Med. 19, 366-373.

44 Slater, E.C. (1953) Biochem. J. 53, 521-530.

45 Scholte, H.R., Luyt-Houwen, I.E.M. and Busch, H.F.M. (1985) J. Inher. Metab. Dis. 8, Suppl. 2, 149-150.

46 Scholte, H.R., Luyt-Houwen, I.E.M. and Vaandrager-Verduin, M.H.M. (1987) Basic Res. Cardiol. 82, Suppl. 1, 63-73.

47 Arts, W.F.M., Scholte, H.R., Loonen, M.C.B., Przyrembel, H., Trijbels, J.M.F. and Luyt-Houwen, I.E.M. (1987) J. Neurol. Sci. 77, 103-115.

48 Church, G.M. and Gilbert, W. (1989) Proc. Natl. Acad. Sci. USA 81, 1991-1995.

49 Maniatis, T., Fritsch, E.F. and Sambrook, J. (1982) Molecular Cloning, A Laboratory Manual, Cold Spring Harbor Laboratory Press, New York.

50 Miller, S.A., Dykes, D.D. and Polesky, H.F. (1988) Nucleic Acids Res. 16, 1215.

51 Meijer, A.J. (1971) Anion Translocation in Mitochondria, Ph.D. Thesis, University of Amsterdam, Academic Service, Amsterdam.

52 Byrne, E. and Trounce, I. (1985) J. Neurol. Sci. 69, 319-333.

53 Scholte, H.R., Busch, H.F.M. and Luyt-Houwen, I.E.M. (1981) in Mitochondria and Muscular Diseases (Busch, H.F.M., Jennekens, F.G.I. and Scholte, H.R., eds.), pp. 133-145, Mefar, Beetsterzwaag.

54 Scholte, H.R., Busch, H.F.M., Van Linge, B., Luyt-Houwen, I.E.M. and Vaandrager-Verduin, M.H.M. (1988) in Actuelle Aspekte neuromuskulärer Erkrankungen (Mortier, W., Pothmann, R. and Kunze, K., eds.), pp. 235-242, Thieme, Stuttgart.

55 Hoppel, C.L., Kerr, D.S., Dahms, B. and Roessmann, U. (1987) J. Clin. Invest. 80, 71-77. 